\title{
ARQUIVOS ESCOLARES: UMA CAIXA DE SURPRESAS COM AS ESPECIFICIDADES E CARACTERÍSTICAS DE UMA INSTITUIÇÃO EDUCATIVA
}

\author{
Roseli Bilobran Klein ${ }^{1}$ \\ Márcia Marlene Stentzler ${ }^{2}$
}

\begin{abstract}
Resumo
Este artigo apresenta resultados do trabalho de catalogação de fontes primárias de instituições escolares, concretizado por meio do Núcleo de Catalogação, Estudos e Pesquisas em História da Educação (Nucathe), da Universidade Estadual do Paraná (Unespar), campus de União da Vitória (PR). As fontes pertencem a arquivos de instituições localizadas na região denominada Vale do Iguaçu, contemplando os municípios de União da Vitória (PR) no sul do Estado do Paraná e de Porto União (SC) no planalto norte catarinense. Esse trabalho tem por objetivo apresentar documentos catalogados e algumas transcrições dos originais, os quais revelam aspectos do cotidiano escolar e da cultura produzida no processo de conformação socioeducacional nas cidades fronteiriças. As fontes aqui relacionadas pertencem às escolas: Casa Escolar Professor Serapião com origem em 1912, remodelada para Grupo Escolar Professor Serapião em 1919 e, a Escola Complementar primária anexa instituída em 1929; o Colégio Santos Anjos criado em 1917; as Escolas Reunidas de Porto União instaladas em 1918, remodelada para Grupo Escolar Professor Balduíno Cardoso no ano de 1927 e, a Escola Complementar anexa criada em 1928. Esse trabalho permitiu reunir fragmentos do passado que mostram aspectos da escolarização na região do Contestado, desvendando "surpresas" e apresentando, por exemplo, as práticas educativas adotadas nesses estabelecimentos de ensino.
\end{abstract}

Palavras-chave: Arquivos escolares. Fontes primárias. Pesquisa documental.

\section{SCHOOL ARCHIVES: A SURPRISE BOX WITH THE SPECIFICITIES AND CHARACTERISTICS OF AN EDUCATIONAL INSTITUTION}

\begin{abstract}
This article presents results from the cataloging of primary sources of school institutions, accomplished through the Center of Cataloging, Studies and Researches in History of Education (Nucathe), of the University of Paraná State (Unespar), the campus of União da Vitória (PR). The sources belong to archives of institutions located in the region called Vale do Iguaçu, covering the municipalities of União da Vitória (PR) in the south of the State of Paraná and Porto União (SC) in the northern plateau of Santa Catarina. This paper aims to present cataloged documents and some transcriptions of the originals, which reveal aspects of daily school and of the culture produced in the process of socio-educational conformation
\end{abstract}


in the border cities. The sources related here belong to the schools: Professor Serapião School House with origins in 1912, remodeled for Professor Serapião School Group in 1919, and the annexed Primary Complementary School instituted in 1929; the Santos Anjos School created in 1917; the Reunion Schools of Porto União, set up in 1918, remodeled for Professor Balduino Cardoso School Group in 1927, and the annexed Complementary School created in 1928. This work allowed us to gather fragments of the past that show aspects of schooling in the Contestado region, unveiling "surprises" and presenting, for example, the educational practices adopted in these educational establishments.

Keywords: School files. Primary sources. Documentary research.

\title{
ARCHIVOS ESCOLARES: UNA CAJA DE SORPRESAS CON LAS ESPECIFICIDADES Y CARACTERÍSTICAS DE UNA INSTITUCIÓN EDUCATIVA
}

\begin{abstract}
Resumen
Este artículo presenta resultados del trabajo de catalogación de fuentes primarias de instituciones escolares, concretado a través del Núcleo de Catalogación, Estudios e Investigaciones en Historia de la Educación (Nucathe), de la Universidad Estadual de Paraná (Unespar), campus de Unión da Vitória (PR). Las fuentes pertenecen a archivos de instituciones ubicadas en la región denominada Vale do Iguaçu, contemplando los municipios de União da Vitória (PR) en el sur del Estado de Paraná y de Porto Unión (SC) en la meseta norte catarinense. Este trabajo tiene por objetivo presentar documentos catalogados y algunas transcripciones de los originales, los cuales revelan aspectos del cotidiano escolar y de la cultura producida en el proceso de conformación socioeducativa en las ciudades fronterizas. Las fuentes aquí relacionadas pertenecen a las escuelas: Casa Escolar Profesor Serapión con orígenes en 1912, remodelada para Grupo Escolar Profesor Serapión en 1919 y la Escuela Complementaria primaria anexa instituida en 1929; el Colegio Santos Anjos creado en 1917; las Escuelas Reunidas de Porto União instaladas en 1918, remodelada para el Grupo Escolar Profesor Balduino Cardoso en el año 1927 y la Escuela Complementaria anexa creada en 1928. Este trabajo permitió reunir fragmentos del pasado que muestran aspectos de la escolarización en la región del Contestado, desvelando "sorpresas" y presentando, por ejemplo, las prácticas educativas adoptadas en esos establecimientos de enseñanza.
\end{abstract}

Palabras clave: Archivos escolares. Fuentes primarias. Investigación documental.

\section{INTRODUÇÃO}

O Núcleo de Catalogação, Estudos e Pesquisas em História da Educação (Nucathe) foi criado com o objetivo de ampliar conhecimentos sobre a História da Educação na região 
sul do Paraná e planalto norte catarinense, por meio da catalogação de documentos arquivados em escolas públicas e privadas. Teve sua origem no ano de 2009, no momento em que o HISTEDBR (Grupo de Estudos e Pesquisas, História, Sociedade e Educação no Brasil) organizava em âmbito nacional, um esforço conjunto para a criação de Grupos de Trabalho para a catalogação de fontes e disponibilização desses materiais para pesquisas. $\mathrm{O}$ grupo de trabalho nasceu da vontade de professores pesquisadores do curso de pedagogia da Universidade Estadual do Paraná (Unespar), campus de União da Vitória ${ }^{3}$.

A partir de levantamento prévio sobre os materiais existentes nas escolas das cidades, posteriormente ampliado para outras escolas da região sul do Paraná e do planalto norte catarinense, desejou-se torná-los públicos a fim de apresentar aspectos da história da educação guardada em arquivos, caixas, prateleiras, gavetas de cozinha, armários e até mesmo debaixo de assoalhos. Uma documentação fechada em si mesma e capaz de desaparecer para sempre caso não houvesse a intencionalidade de catalogação e registro dos documentos, fontes para a pesquisa.

O trabalho inicial junto às escolas, com o intuito de sondagem, revelou aspectos da riqueza cultural, social e política que envolvia esse conjunto de estabelecimentos educacionais, formando um importante pólo educacional, desde sua origem. Esse fato despertou um desejo de conhecer o espaço micro dessas instituições, para contextualizá-las no universo macro da história da educação brasileira. Entre os trabalhos já publicados a partir desses arquivos, encontram-se: Klein, Schena e Stentzler (2009); Stentzler (2015); Stentzler e Ferreira (2016); Stentzler e Kobelinski (2017); Schena (2015); Klein (2014; 2015; 2016; 2017).

As cidades, onde se situam as referidas escolas são fronteiriças, localizam-se junto ao Rio Iguaçu ${ }^{4}$ e a história da educação em ambas entrelaça-se aos aspectos históricos da origem comum: a antiga cidade de Porto União da Vitória ${ }^{5}$ (PR) que foi caminho de tropas e, em 1905, recebeu os trilhos do trem em sua margem direita. A ferrovia tornou-se o grande símbolo do progresso, juntamente com a Casa Escolar Professor Serapião, que recebeu essa denominação pelo Decreto $\mathrm{n}^{\circ}$ 324, de 13 de abril de 1912. (PARANÁ, 1914, p. 120). A construção do edifício foi concluída no primeiro semestre de 1913. Conforme Camargo (1913, f. 144), as chaves do estabelecimento foram entregues pelo construtor ao Inspetor Escolar abrigando, inicialmente, "“[...] três escolas isoladas que funcionavam separadamente [...]" embora a casa escolar comportasse quatro escolas: duas masculinas e duas femininas. (STENTZLER, 2015, p. 61).

Entre 1912 e 1916, a região que compreende o sul do Paraná e o planalto norte de Santa Catarina foi assolada pela Guerra do Contestado ${ }^{6}$, envolvendo sertanejos, madeireiras, forças civis e militares. Paraná e Santa Catarina disputavam o território. Em 1916, os governadores dos dois Estados litigiantes assinaram o Acordo de Limites ${ }^{7}$, dividindo a população e o território da cidade de Porto União da Vitória (PR). Os trilhos da ferrovia 
tornam-se marco divisório, criando uma fronteira interestadual onde antes era território paranaense: de um lado a cidade de União da Vitória (PR) e do outro a de Porto União (SC). Em um mesmo conjunto urbano coexistiram escolas, em instituições mantidas pelo Estado, ou privadas, vinculadas a diferentes etnias, ou à Igreja Católica. As escolas das duas cidades obedeciam a legislações específicas dos Estados do Paraná e de Santa Catarina.

O trabalho de pesquisa realizado junto aos arquivos escolares revelou o rico cenário em que as instituições das duas cidades se situavam. O levantamento de fontes compreende os arquivos do Grupo Escolar Professor Serapião ${ }^{8}$ e da Escola Complementar Primária anexa, (PARANÁ, 1914; 1929); das Escolas Reunidas, remodeladas no Grupo Escolar Professor Balduíno Cardoso e, a Escola Complementar criada anexa a esse estabelecimento e transformada em Escola Normal Primária (SANTA CATARINA, 1919; 1928; 1929; 1936; 1939); e Colégio Santos Anjos (1917), uma instituição confessional, com os respectivos cursos anexos, escola complementar e escola normal primária. Os documentos revelam a ação dos diretores dos estabelecimentos, dos inspetores escolares que realizavam as visitas de inspeção, o acompanhamento de autoridades civis, militares e eclesiásticas.

Consideradas as especificidades da pesquisa, Pintassilgo e Pedro (2012, p. 2) indicam que fontes documentais também revelam "[...] estilos próprios de liderança e de relações interpessoais [...]" de diretores, o que influencia o cotidiano escolar, organizado a partir de normas pré-estabelecidas. Os professores orientam o processo de ensino e aprendizagem dos estudantes na medida em que adotam encaminhamentos didático-pedagógicos. Quanto aos alunos torna-se possível reconhecer o papel dinâmico que desempenharam pelas suas atitudes e resultados descritos em documentos.

Este trabalho apresenta fragmentos de documentos existentes nos arquivos escolares desvendando temas que se desdobram em categorias como: instituições, cultura escolar, práticas pedagógicas, cultura material escolar, espaço escolar, processos socioeducacionais, entre outras, que podem servir para pesquisadores da história da educação. Neste artigo, no primeiro momento, são apresentados documentos do Grupo Escolar Professor Serapião e escola Complementar Primária anexa; em seguida registrados fragmentos documentais do Grupo Escolar Professor Balduíno Cardoso, Escola Complementar e Escola Normal Primária anexa; e na sequência fontes primárias do Colégio Santos Anjos.

\section{DE CASA ESCOLAR A GRUPO ESCOLAR PROFESSOR SERAPIÃO (UNIÃO DA VITÓRIA - PR): DOCUMENTAÇÃO DOS ARQUIVOS ESCOLARES}

Inicialmente a Casa Escolar Professor Serapião funcionou em um edifício entregue à população da cidade de Porto União da Vitória (PR), em 1913 (Fotografia 1). Com o Acordo de Limites estabelecido em 1916, ao fim da Guerra do Contestado, o prédio passou a 


\section{Revista HIIS'TEIDBR (Dn-line}

jurisdição catarinense e a partir de 1918 foi utilizado para as Escolas Reunidas de Porto União (SC). O governo paranaense construiu um novo prédio onde funcionou o Grupo Escolar Professor Serapião, em União da Vitória (PR), após a divisão da cidade, em 1917.

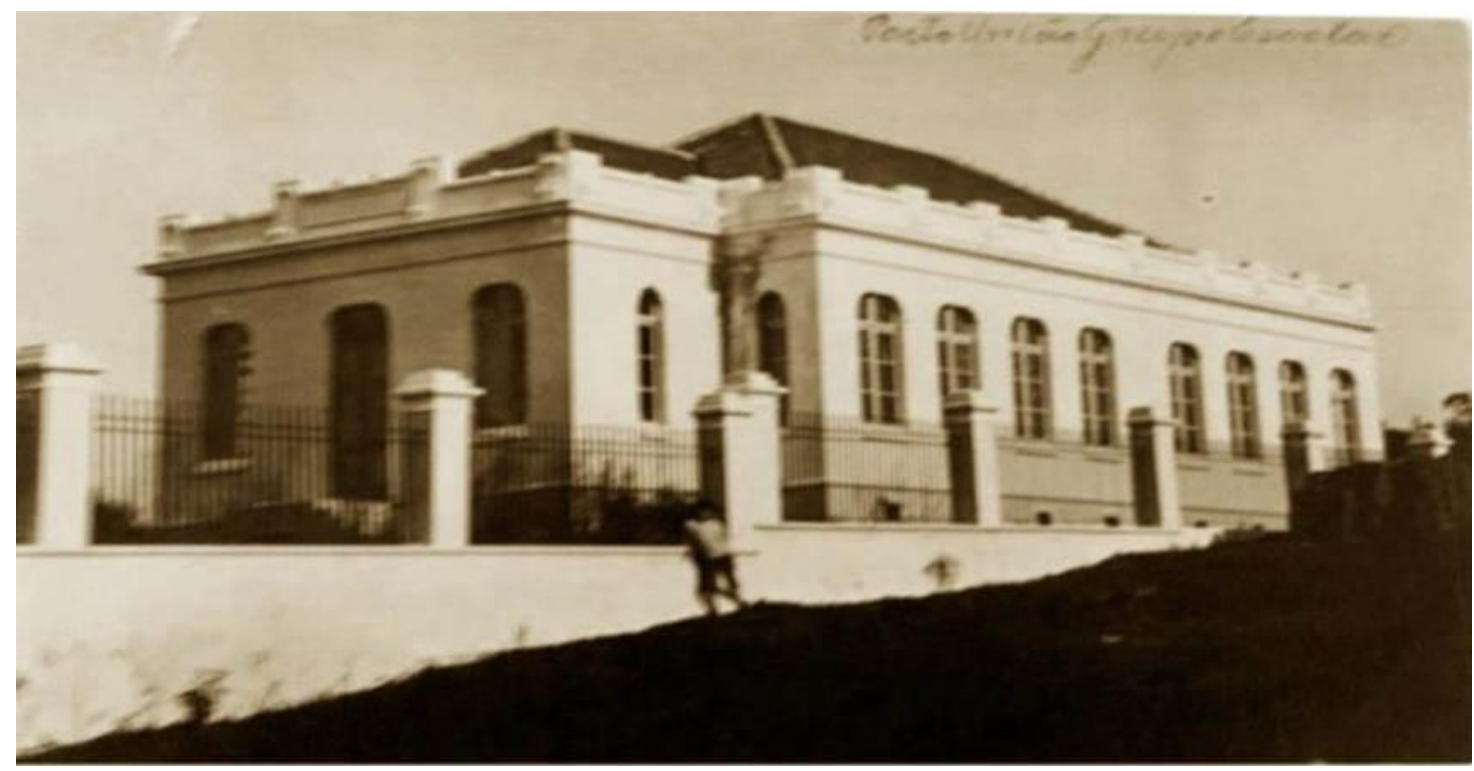

Fotografia 1 - Prédio do Grupo Escolar Professor Serapião, construído em 1913. Fonte: Acervo do Nucathe, [s/d].

Em relação a essa escola, o material inventariado reúne cerca de trinta fontes primárias catalogadas e analisadas, com registro de acervo iconográfico significativo e transcrição total dos documentos encontrados no arquivo, que atualmente está sob a guarda da Escola Municipal Professor Serapião, funcionando no mesmo estabelecimento que foi construído em 1917. Com cem anos de existência, as fontes constituem-se um número pequeno, entretanto são valiosas, pois a mais antiga foi redigida em 1915, a próprio punho pela Professora normalista Amasilia Pinto de Araújo. Essa educadora chegou à cidade em 1904. Todo o acervo, juntamente com o prédio ${ }^{9}$, faz parte do Patrimônio Histórico Cultural, tombado em 1988. (KLEIN, 2013). Os documentos destacam a história dos atores escolares, tempo e espaço escolar, aspectos da prática pedagógica, funções administrativas, registro de notas, reuniões pedagógicas, visitas de inspetores, comemorações cívicas, diplomas, entre outros. (KLEIN, 2013; STENTZLER, 2015).

Entre as fontes primárias catalogadas nesse Grupo Escolar, de acordo com Klein (2013), existem: Atas de Visitas de Inspetores (1915-1931); Termo de Posse das Professoras registrado em livro próprio denominado Promessas das Professoras (1928); Livro de Atas da Escola Complementar (1933 - 1941); Livro de Penas aplicadas aos alunos (1935); Livro de Registro de Suspensão e de Repreensão a Professores e Funcionários (1937- 1964); Arquivo das Provas Mensais (1941); Registro de Diplomas do Curso Primário (1943 1946); Livro de Registro dos Exames Finais da Quarta Série do Curso Primário (1946 - 
1971); Livro Ata das Reuniões Pedagógicas Mensais (1950 - 1955); Registro das Atividades de Início das Aulas (1954 - 1966); Premiações e Tarefas Administrativas (1955 - 1971); Livro de Honra ao Mérito (1956 - 1970); Registro de Ofícios (1960 - 1973); Livro de Termo de Compromisso (1960 - 1998); Livro de Registro de Visitas (1963 - 2002); Implantação do Pré-Escolar (1973); Livro de Atas de Avaliações Finais (1974 - 1994).

No momento da catalogação e registro fotográfico, os materiais encontravam-se em bom estado. Todos são manuscritos, em formato livro ata, com páginas numeradas. $\mathrm{O}$ primeiro registro, de 19 de novembro de 1915, redigido pela professora Amasilia Pinto de Araújo e intitulado Resultado dos Exames Finais, destaca:

Aos 19 dias do mêz de novembro de 1915, na cidade de União da Victória, numa das salas do Grupo Escolar Professor Serapião, onde funcciona a escola regida pela professora normalista Amasilia Pinto de Araújo presente a comissão examinadora composta do Sr. Dr. Rivadávia Amazonas, Inspector Escolar desta cidade como presidente e as examinadoras D. Ondina Cordeiro Machado e D. BernardinaSchleder. Às dez horas da manhã iniciaram-se os exames finaes e parciais das alumnas da referida escola. Procedendo-se a chamada verificou-se o comparecimento de 37 alumnas, deixando de comparecer 22. Feita a prova escripta e em seguida a prova oral de conformidade com as disposições regulamentares em vigor, a commissão exarou na prova escrita as notas detalhadas por matéria o que deu logar ao resultado final seguinte [...]. (GRUPO ESCOLAR PROFESSOR SERAPIÃO, 1915, p. 21).

O Termo de Visitas e Inspeções Escolares, em16 de novembro de 1929, relata que o estabelecimento recebeu uma inspeção médica escolar, cujas anotações foram as seguintes:

Em serviço de inspeção médica visitei o Grupo Escolar Professor Serapião examinando 112 alumnos presentes dos 135 matriculados no $4^{\circ}, 3^{\circ}$ e $2^{\circ}$ feminino, $1^{\mathrm{a}} \mathrm{C}$ e $1^{\mathrm{a}} \mathrm{B}$ mistas, certificando a existência de 5 pediculoses, 22 verminóticos, 2 escabioses e 5 com outras afecções. Foram fornecidas 28 receitas e foram vacinados 58 alumnos que ainda não o haviam sido. Embora há poucos dias a Ilma. Professora Myriam de Souza tenha assumido a direção desta casa, sente-se que é uma directora capaz de elevar os casos de saúde do Grupo Escolar, Complementar e Jardim da Infância sob sua orientação clara e segura, e com o devido progresso que honrará sobre o nosso Estado. Já se faz necessária a construção de um novo prédio escolar que comporte a freguesia que se eleva dia-a-dia. (GRUPO ESCOLAR PROFESSOR SERAPIÃO, 1929, p. 20v).

A preocupação com a higiene relacionava-se com a intenção de cuidar dos estudantes, livrando-os de moléstias e doenças do início do século XX, que dizimavam muitas crianças, diminuindo a expectativa de vida e a possibilidade de vê-las como sujeitos produtivos numa sociedade que se transformava e se modernizava. As medidas voltavam-se para a repetição de hábitos de higiene que eliminassem a vulnerabilidade das doenças como: o asseio corporal e do ambiente, bem estar físico, ausência de doenças e alimentação saudável entre outros. Também a educação física higienista tinha como meta resolver o problema da saúde pública pela educação. 


\section{Revista HIISTEYIDIR On-line}

Em 4 de janeiro de 1929, o Governador do Estado do Paraná, Afonso Camargo, assinou o Decreto ${ }^{0} 33$, criando a Escola Complementar primária anexa ao Grupo Escolar. (PARANÁ, 1929). Em dezembro de 1933, em um livro ata, registrou-se a conclusão dos estudos da Escola Complementar Primária, habilitando os alunos a prosseguirem estes junto às Escolas Normais do Estado. O Registro de Diplomas da Escola Complementar Primária segue o padrão:

República dos Estados Unidos do Brasil. Diretoria Geral da Instrução Pública. Estado do Paraná. Curso Complementar Primário. Eu Brasílio de França Costa, Diretor da Escola Complementar Primária, anexa ao Grupo Escolar Professor Serapião da cidade de União da Vitória, confiro a aluna..., nascida em..., filha de..., tendo em vista os exames finais deste curso a que se submetem, o presente diploma à matrícula no $1^{\circ}$ ano das Escolas Normais do Estado. União da Vitória, 9 de dezembro de 1933. O Diretor Brasílio de França Costa, a diplomada..., Aprovada com nota... Registrado à folha... do livro competente. Em 9 de dezembro de 1933. O Diretor, Brasílio de França Costa. Copiado por Maria José M. Frank. (GRUPO ESCOLAR PROFESSOR SERAPIÃO, 1933, p. 37).

Um documento que merece destaque é o Registro de Suspensão e de Repreensão a Professores e Funcionários (1937 - 1964) onde se lavravam termos de suspensões a professores por: ausência a aulas sem justificativa; desrespeito à Diretora; aplicação de castigos corporais a alunos. O livro reúne informações quanto a repreensão a funcionários, conforme segue:

A Sra. Professora X está suspensa por um espaço de três dias, em virtude de ter faltado com o devido respeito a esta diretora (01 de outubro, 1937).

Termo de suspensão da Guardiã X, suspensa por espaço de três dias a guardiã por faltar com devido acatamento às ordens que desta diretoria são emanadas e que por várias vezes de acordo com o regulamento interno chamei-lhe a atenção (11 de novembro de 1937).

Em data de 25 de setembro de 1943 suspendo a professora efetiva de $1^{\mathrm{a}}$ classe, $\mathrm{X}$, pelo espaço de três dias a contar desta data, de acordo com o Art. $16^{\circ}$, letra d, combinado com o Art. $17^{\circ}$, letra d, parágrafo III, do Regimento Interno dos Grupos Escolares do Estado do Paraná, por ter imposto castigo corporal ao aluno X, da classe do $3^{\circ}$ ano masculino, regido pela professora X. (25 de setembro de 1943). Repreendo as professoras 1, 2, 3, 4, 5, 6 e 7 bem como as zeladoras 1, 2, 3 e 4, que deixaram de comparecer ontem à Missa Campal em ação de graças pelo término da Guerra na Europa, onde estavam lutando por causa justa, os nossos irmãos e que não foi atendido o pedido verbal desta direção, para o comparecimento, não sendo cabível outra penalidade, em virtude da falta de patriotismo das mesmas e de desrespeito às ordens de seus superiores. Deixo de repreender a professora $\mathrm{X}$, em virtude de a mesma ter mandado avisar o motivo do não comparecimento bem como as professora 1, 2, 3 e 4, por não terem comparecido no sábado último. (4 de maio de 1945).

Fica suspensa por três dias a partir de hoje, por haver infringido ordens do Regimento Interno, Art. 12, parágrafo $2^{\circ}$, a servente X. (4 de agosto de 1948).

Conforme determinação do Exmo. Sr. Clodoaldo Naumann, Delegado de Ensino, suspendo por trinta dias a partir desta data, a professora nível $1, \mathrm{X}$, lotada neste Estabelecimento, de conformidade com o que preceitua o Art. 217 e seu parágrafo da Lei n ${ }^{\circ} 293$ de 24-11-49 dos Estatutos dos Funcionários Públicos e Civis do Estado, por ter a mesma cometido falta grave no desempenho de suas funções 


\section{Revista HIIST'TEIDBR On-line}

ISSN: 1676-2584

Artigo

doi: $10.20396 /$ rho.v18i2.8651906

quando prestava serviços no Colégio Estadual "Túlio de França” (18 de fevereiro de 1964). (GRUPO ESCOLAR PROFESSOR SERAPIÃO, 1937-1964, p. 1-11).

Esses documentos foram produzidos num contexto sócio histórico onde prevalecia o rigor disciplinar, ideias de cunho nacionalizante e ampliação da escolarização entre jovens, que por meio da Escola Complementar Primária anexa, recebiam formação oportunizandoos a assumirem funções públicas, especialmente como professores de escolas primárias rurais. A história do Grupo Escolar Professor Serapião relaciona-se diretamente aos primórdios da história da escola pública na região Sul do Paraná, em substituição aos antigos mestres-escolas.

\section{DE ESCOLAS REUNIDAS A GRUPO ESCOLAR PROFESSOR BALDUÍNO CARDOSO (PORTO UNIÃO - SC)}

A Lei no 1147 de 25 de agosto de 1917 criou o Município e Comarca de Porto União (SC). (SANTA CATARINA, 1917, p. 6-7). Em virtude do Acordo de Limites, as escolas que funcionavam no Grupo Escolar Professor Serapião foram transferidas para território paranaense. Em 28 de setembro de 1918, no prédio onde funcionava o Grupo Escolar Professor Serapião até aquele momento, iniciaram-se atividades das Escolas Reunidas de Porto União (SC). (MILIS, 2002, p. 80).

Cronologicamente, a Resolução no 1196 de 20 de junho de $1918^{10}$ (SANTA CATARINA, 1919) trata-se do primeiro documento localizado que informa sobre a criação das Escolas Reunidas na cidade, designando o "[...] diretor do Grupo Escolar Conselheiro Mafra, de Joinville, [...] para auxiliar o serviço de instalação [...] das Escolas Reunidas de São Bento, Mafra e Porto União.” (STENTZLER, 2015, p. 83). Em 1927 recebeu a denominação de Grupo Escolar Professor Balduíno Cardoso; em 1928 iniciaram-se as atividades da Escola Complementar ${ }^{11}$ anexa, a qual entre 1935 e 1938 funcionou como Escola Normal Primária e, deixou de existir em 1939, quando foi criado um Curso Complementar. (SANTA CATARINA, 1928; 1929; 1936; 1939). A imagem abaixo (Fotografia 2) revela aspectos do prédio e estudantes do Grupo Escolar Professor Balduíno Cardoso, com significativo número de alunos. Na escadaria visualizam-se estudantes maiores, possivelmente alunos e alunas da Escola Complementar anexa, que na década de 1940, foi remodelada para Curso Normal Ginasial. 


\section{Revista HIIS'TEIDBR (Dn-lime}

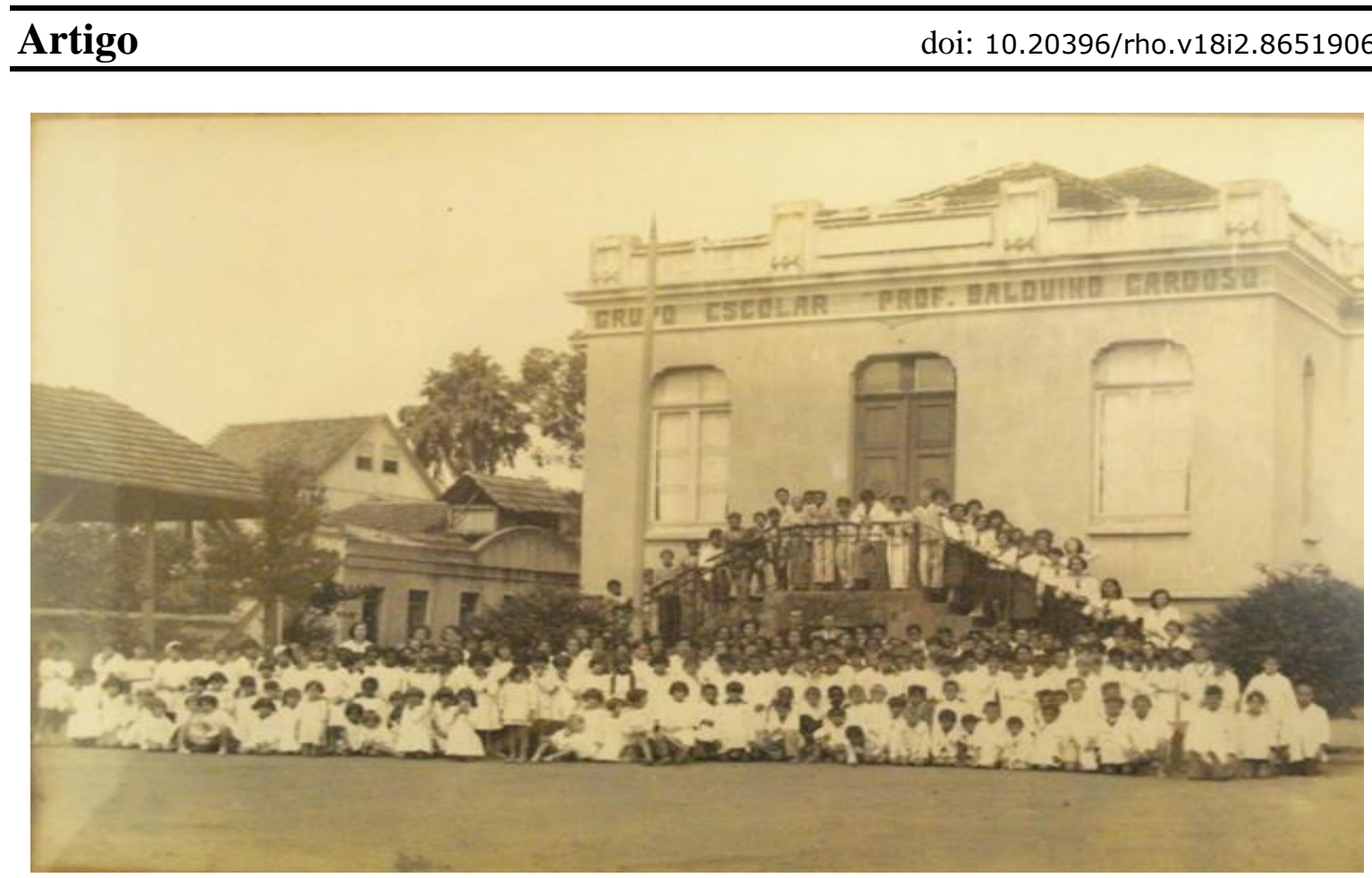

Fotografia 2 - Grupo Escolar Professor Balduíno Cardoso. Fonte: Acervo do Museu Municipal de Porto União, [192?].

No arquivo do Grupo Escolar Balduíno Cardoso foram catalogadas cerca de 350 fontes primárias, como por exemplo, os livros de visitas assinados por autoridades, os livros destinados aos inspetores escolares, os registros das reuniões pedagógicas, relatórios anuais do curso primário, da escola complementar e normal primária, entre outros ${ }^{12}$.

Um dos documentos que revelam as origens da escolarização, na cidade de Porto União (SC), trata-se do Livro de Termos de Visitas das Escolas Reunidas de Porto União, aberto em 1918. Caracterizando-se como Livro Ata, com dimensão aproximada de trinta e três centímetros por vinte e dois $(33 \mathrm{~cm} \mathrm{X} 22 \mathrm{~cm})$, paginação sequencial e bom estado de conservação (Fotografia 3). O livro recebeu registros de visitantes ilustres até setembro de 1969. 


\section{Revista HIIS'TWIDBR On-lime}

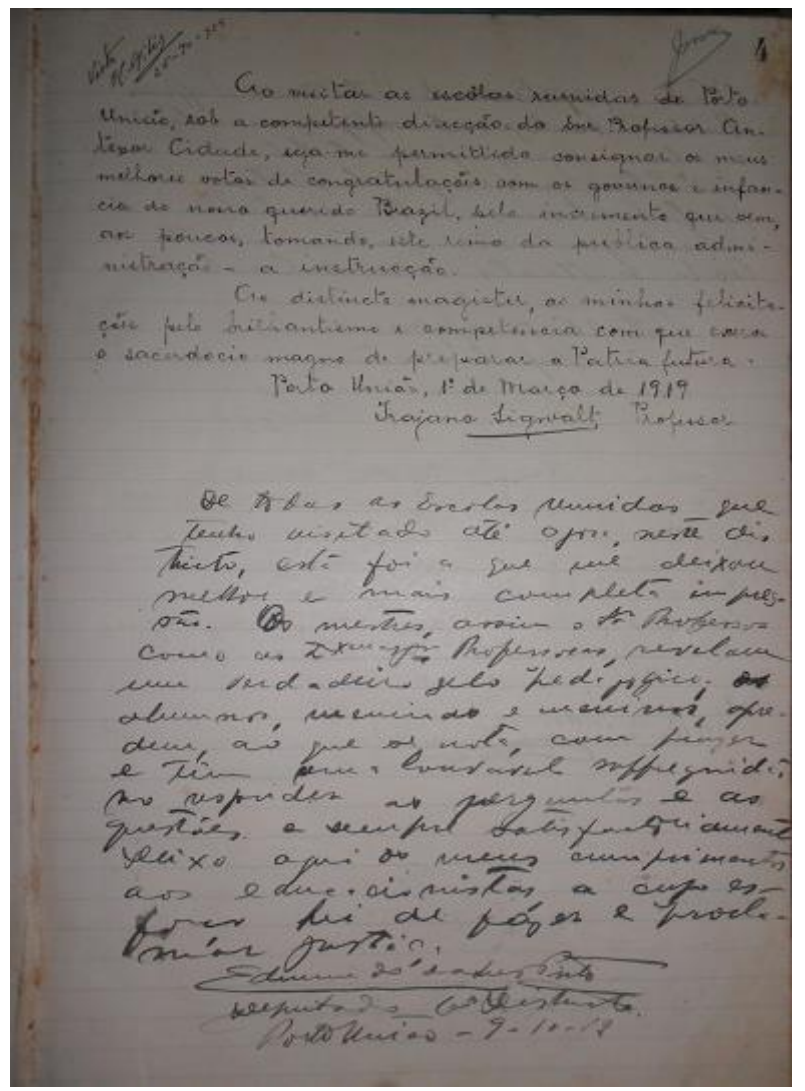

Fotografia 3 - Primeiro e segundo registro de visitas de autoridades. Fonte: Acervo do Grupo Escolar Professor Balduíno Cardoso, 1919.

Os primeiros registros do livro, acima, marcam aspectos da educação nas cidades fronteiriças, denotando a inter-relação promovida pela educação nas cidades fronteiriças. $\mathrm{O}$ primeiro foi redigido pelo professor Trajano Sigwalt, diretor do Grupo Escolar Modelo Xavier da Silva, de Curitiba, em março de 1919. O referido educador trabalhava na remodelação do Grupo Escolar Professor Serapião, na vizinha cidade paranaense. A criação de escolas primárias constituía-se motivo para congratulações a governos e à infância brasileira, ultrapassando fronteiras interestaduais. O segundo registro, realizado por um deputado catarinense, atesta o zelo pedagógico com que a educação era tratada nas Escolas Reunidas de Porto União (SC).

O Livro de Promoção dos alunos da Escola Complementar anexa, cujo termo de abertura foi redigido pelo Professor Estevão Juk, diretor do estabelecimento, em 27 de fevereiro de 1930, apresenta apenas registros de promoções dos alunos do $1^{\circ}$ e do $2^{\circ}$ ano, em 1930. (ESCOLA COMPLEMENTAR ANEXA AO GRUPO ESCOLAR PROFESSOR BALDUÍNO CARDOSO, 1930).

As Atas de Exames da Escola Complementar anexa ao Grupo Escolar Professor Balduíno Cardoso foram lavradas em livro próprio, com termo de abertura de 24 de abril de 1928, pelo Diretor Manuel Donato da Luz. As cinquenta páginas encontram-se rubricadas e 
numeradas; nelas constam as atas de instalação da escola, em 1928, e exames da primeira turma da Escola Complementar; exames vagos; segunda época e exames finais entre $1931 \mathrm{e}$ 1938. (ESCOLA COMPLEMENTAR ANEXA AO GRUPO ESCOLAR PROFESSOR BALDUÍNO CARDOSO, 1928-1938).

Livro com as Atas de Exames da Escola Normal Primária anexa ao Grupo Escolar Balduíno Cardoso, cujo termo de abertura foi redigido pelo Diretor Gregório Berkenbrok, em $1^{\circ}$ de dezembro de 1938, apresenta os exames finais daquele ano. (ESCOLA NORMAL PRIMÁRIA ANEXA AO GRUPO ESCOLAR PROFESSOR BALDUÍNO CARDOSO, 1938).

O livro denominado Registros de Diplomas da Escola Complementar, anexa ao Grupo Escolar Balduíno Cardoso, teve o termo de abertura realizado pelo primeiro diretor, Antônio Gasparello. Nele constam 50 folhas, com 37 utilizadas, todas rubricadas, manuscritas e sequenciais. (ESCOLA COMPLEMENTAR ANEXA AO GRUPO ESCOLAR PROFESSOR BALDUÍNO CARDOSO, 1931-1941).

O Livro Ponto dos Funcionários da Escola Complementar anexa ao Grupo Escolar Professor Balduíno Cardoso, compreende o período de existência da Escola. Encontram-se no formato manuscrito e estão em boas condições, com páginas rubricadas e assinaturas diárias do Diretor, serventes e das professoras normalistas. (ESCOLA COMPLEMENTAR ANEXA AO GRUPO ESCOLAR PROFESSOR BALDUÍNO CARDOSO, 1934-1935).

Os Livros de Matrícula para a Secção Masculina e para a Secção Feminina da Escola Complementar anexa ao Grupo Escolar Professor Balduíno Cardoso, foram abertos em 28 de abril de 1928 e utilizados até a década de 1960. Constituem-se em dois documentos reunindo as matrículas de todos os estudantes que frequentaram a Escola Complementar (1928-1934), a Escola Normal Primária (1935-1938), e outros cursos pós-primários ofertados nos anos seguintes. Cada estudante recebia um cadastro com: número da matrícula; número de ordem do aluno; nome; idade (dia, mês e ano); naturalidade; filiação; profissão do pai; época da inscrição; ano do curso; eliminação (datas e causas); observações. (ESCOLA COMPLEMENTAR ANEXA AO GRUPO ESCOLAR PROFESSOR BALDUÍNO CARDOSO, 1928-1964a; 1928-1964b).

O rico acervo da instituição revela inúmeros aspectos da cultura escolar gerada em seu interior. Resgatar essa realidade, catalogar, transcrever fontes primárias faz parte de um primeiro e fundamental passo para consolidar o estudo da instituição e disponibilizar informações para pesquisadores na área. $\mathrm{Na}$ sequência registram-se fragmentos de documentos existentes ${ }^{13}$, com o intuito de ilustrar as potencialidades das fontes. As anotações apresentam-se manuscritas, no formato de livro ata com capa dura.

O relatório do Inspetor Escolar João Romário Moreira, se encontra no Livro Ata de Visita de Inspeção Escolar, redigido em decorrência da inspeção realizada nos dias 26, 28 e 29 de abril de 1919. O documento revela que o prédio e o terreno onde funcionavam as 


\section{Revista HIISTEYIDIR On-line}

Escolas Reunidas de Porto União encontrava-se em condições inadequadas de higiene, naquele momento:

Em obediência a determinações superiores estive em visita às Escolas Reunidas desta cidade nos dias 26, 28, e 29 de abril de 1919, onde observei o seguinte: I Do prédioe suas dependências - o prédio apresenta diversas goteiras que muito prejudicarão o madeiramento caso em breve não se façam os necessários reparos. O pátio de ambas as seções apresentava um aspecto desagradável, parecendo terreiro de uma casa abandonada. Tal era a grande quantidade de hervas danninhas nelle contidas a 26 de abril. Além disso, por ser o terreiro de argila vermelha e muito liguenta, nos dias de chuva a creançada conduz grande quantidade de terra para o interior do estabelecimento impressionando mal aos visitantes e condennando a higyene das salas. Os dejectórios mal asseados por falta do assento de madeira e do funccionameto das caixas d'água, cuja bomba elevadora acha-se estragada, repugnam as creanças satisfazerem suas necessidades physiológicas, o que é pedagogicamente condennável. De mais a mais, as enxurradas invadem as casinhas tornando-as inoccupáveis [...]. (MOREIRA, 1919, p. 4-5).

Em setembro de 1939, já nas instalações do novo prédio inaugurado em maio de 1938, o Inspetor Escolar Germano Wagenführ realizou uma visita ao Grupo Escolar Professor Balduíno Cardoso, elaborando o seguinte relatório:

Nos dias letivos de 5 a 18 de setembro de 1939, visitei o Grupo Escolar Balduíno Cardoso e Curso Complementar anexo de Porto União, que está sob a direção do senhor professor Gregório Berkenbrock e observei o seguinte: 1) Do Prédio e suas Dependências - todos estes estão ainda em perfeito estado de conservação, notando-se em tudo a mais perfeita ordem e asseio, e são providos de todos os requisitos higiênicos e pedagógicos. Também foi instalada água encanada e pias nos varandões. Em uma das salas da frente foi instalado o gabinete dentário. Num terreno contíguo ao estabelecimento que foi adquirido pelo Estado, está prestes a ficar concluído o campo desportivo. 2) Das áreas do Recreio e Jardim - nas áreas do recreio há mais perfeita ordem e asseio. O Jardim está florido e cheio de roseiras, arbustos e muitas outras flores. Para evitar que os alunos cheguem aos muros que cercam o Grupo, encontram-se canteiros em toda a sua extensão lateral e frente. As trepadeiras que deverão formar o caramanchão, já estão bem desenvolvidas. 3) Do Clube Agrícola - a área deste já está toda preparada e quase tudo plantado e semeado. Encontram-se canteiros de batata, repolho, ervilhas, rabanetes, trigo, espinafre, beterrabas, etc. $\mathrm{O}$ que deu mais rendimento neste ano foi a plantação de aipim. 4) Da Biblioteca - esta conta atualmente com 98 volumes das séries pedagógicas e didáticas, 112 livros de leituras recreativas, 220 revistas, boletins e outros folhetos. Foram adquiridos 4 livros didáticos e 6 de leitura recreativa. 5) Da Caixa Escolar - o movimento desta foi, até a presente data, o seguinte: receita 1:568\$000 e a despesa também de 1:568\$000. Esta instituição tem cooperado muito para o pleno funcionamento das aulas, pois fornece todo o material escolar para todos os alunos. 6) Do Mobiliário - é muito bom o estado de conservação do mobiliário deste Grupo, entretanto, muitas carteiras sofreram algo pela ação do sol, visto terem faltado cortinas até esta data. 7) Do Material Didático - há ainda a falta de um gabinete de física e química, quadros anatômicos do sistema nervoso e muscular; mapas da Europa, Ásia, África, Oceania e das Américas, bem como um relógio para cada sala de aula. 8) Da Escrituração - toda escrituração dos livros e fichas estava em dia e em ordem tanto o que estava a cargo das senhoras professoras quanto àquela que estava a cargo do senhor Diretor. 9) Da Disciplina em Geral - esta foi em todo o sentido muito boa, quer 


\section{Revista HIST'TEIDBR Om-line}

seja nas marchas da entrada, saídas, formaturas e recreios, quer no uso do material dos alunos. (WAGENFUHR, 1939, p. 44v-49v).

No dia 24 de agosto de 1951, durante Reunião Pedagógica presidida pelo Inspetor Escolar Germano Wagenführ, registrou-se em ata aspectos da organização de Associações Escolares no referido estabelecimento:

Biblioteca Escolar - o senhor Inspetor achou que a biblioteca passou por uma grande e benéfica reforma, merecedora de elogios. Está bem organizada, apesar de estar faltando grande número de livros, que caíram em mãos de crianças descuidadas. Sugeriu para que fosse feita uma campanha, onde cada criança que tivesse um livro da biblioteca, em casa, entregasse, o quanto antes, para a professora X encarregada dessa Associação. Está, pois, de parabéns, a senhora professora, pela dedicação e esforço que tem demonstrado nos seus trabalhos. Pelotão de Saúde - deseja o senhor inspetor que haja trabalho mais intenso quanto à higiene dos alunos. Que se faça revista diária, pelos alunos mais asseados e comportados, não só revista pessoal, como no material. Fazendo, assim, esperase, que melhore o aspecto das crianças. Liga Pró-Língua Nacional - gostou do andamento dessa associação. Achou que a reforma dos álbuns está em grande atividade e que a correspondência está sendo bem atendida. Quanto as demais associações, pediu que cada professora encarregada desempenhe, na íntegra, seu serviço. Beneficência dos Professores - nenhuma recomendação foi dada, pois encontrou tudo em ordem. Campanha do Cruzeiro_- lembrou que seria interessante fazer uma campanha, pelo rádio, preparando o espírito do povo, fazendo-lhe ver para que fim arrecadaremos esse cruzeiro. Lição de Casa - deseja que haja sempre uma lição para casa. Não deve ser difícil; deve ser matéria já passada e fácil, para evitar a intervenção dos pais. Os deveres passados, quer de linguagem ou aritmética, devem ser curtos, para facilitar a correção, em aula, não se precisando, assim, perder tanto tempo. Jamais a professora deverá passar uma lição sem dar nota. Correção dos cadernos em aula - pede o senhor inspetor, que a correção dos cadernos deve ser feita até o ponto em que a criança está ocupada no exercício. $\mathrm{O}$ caderno não deverá ser entregue sem a nota, pois o primeiro impulso que a criança tem, é olhar para a nota. Pede também, que se faça correção de todos os erros, logo que for entregue o caderno para o aluno. Nos desenhos, na caligrafia e cartografia, é obrigatório pôr nota, a nota estimula o aluno. Ensino de Caligrafia - quanto ao ensino de caligrafia já está perfeito em algumas classes. Ao ministrar uma aula de caligrafia, a professora procederá da seguinte maneira: traçar as linhas no quadro; escrever palavra por palavra; letra bem vertical e fazer um exercício pequeno. Enquanto as crianças fazem o exercício, a professora percorrerá a sala, auxiliando onde for preciso. Ensino da Higiene - o ensino da higiene está ligado ao Pelotão de Saúde. No primeiro ano a professora terá o assunto da higiene pessoal. Ensinar como a criança deve vir para a aula; cortar as unhas semanalmente; tomar seu banho diário; pentear-se bem, etc. Nos $2^{\text {os }}, 3^{\text {os }}$ e $4^{\text {os }}$ anos, onde a compreensão é maior, aproveitar as epidemias, como as de tifo, varicela, etc, ensinando-lhes quais os meios de se evitar tais doenças e as precauções a tomar. Ensino de Geometria - o ensino de geometria está coligado ao ensino de aritmética. O problema de geometria só ditado não basta. O aluno deve conhecer o metro, divisão do metro, saber o que é perímetro, aresta, etc. Ciências e Geografia - como disse o senhor inspetor, o programa não está adaptado à classe, mas não se pode fazer com que os alunos sofram, com essas matérias. Sugeriu que se desse apenas a metade do programa e resumidamente. Foi aprovada a idéia da professora $\mathrm{X}$ quanto ao ensino de Ciências, o senhor inspetor acha melhor que se faça de cada ponto um esquema. Dar primeiro o assunto, explicando o ponto todo, depois o esquema. Tendo o esquema, o aluno gravará melhor o ponto. Pediu, o senhor inspetor, que se 


\section{Revista HIISTEIDBR (On-line}

fizessem Centros de Interêsse, de proveito, para cada classe. Nada mais havendo a tratar, encerrou-se a reunião [...]. Porto União, 24 de agosto de 1951. (GRUPO ESCOLAR PROFESSOR BALDUÍNO CARDOSO, 1951-1957, p. 5v-7v).

As associações escolares fizeram parte da cultura dos grupos escolares catarinenses, com o intuito de ressignificar a escola primária a partir dos preceitos escolanovistas (PRATES; TEIVE, 2013). No Grupo Escolar Professor Balduíno Cardoso, as associações compunham-se por professores e estudantes. Realizava-se o registro de suas atividades em livro próprio e, ao final do ano letivo, esses integravam os relatórios anuais das atividades escolares da instituição.

Um Livro de Honra ao Mérito marcou a educação no estabelecimento. Nele registravam-se os nomes de alunos que se destacavam com boas notas, assiduidade e bom comportamento. O registro separava estudantes por série. A imagem abaixo (Fotografia 4) revela aspectos do documento assinado por poucos estudantes, os quais também assumiam o compromisso de tornarem-se alunos ainda melhores. Os desenhos e colagens apresentamse únicos, em cada página dos livros, reunindo registros a partir da década de 1930.

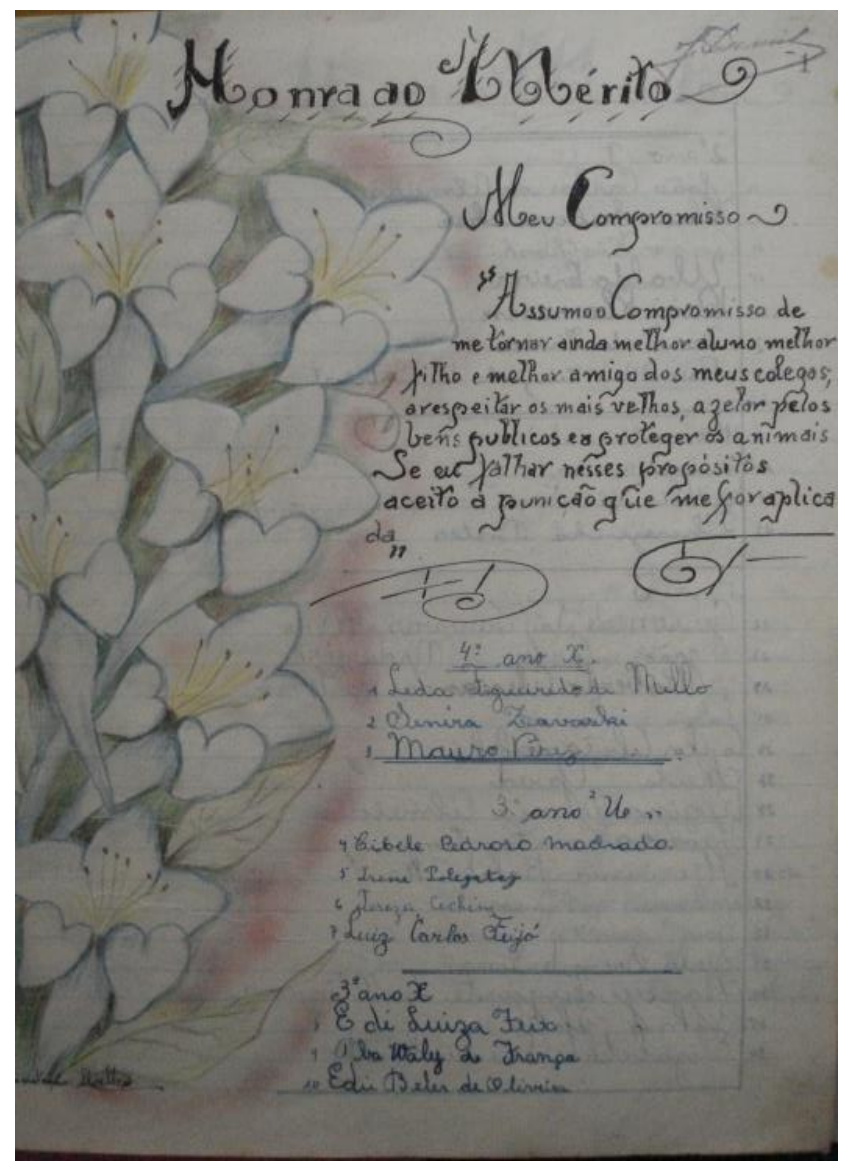

Fotografia 4 - Honra ao Mérito.

Fonte: Acervo do Grupo Escolar Professor Balduíno Cardoso, 1952. 


\section{Revista HIIST'TEIBR On-lime}

O trabalho empreendido em relação às fontes primárias das Escolas Reunidas de Porto União, posteriormente transformadas em Grupo Escolar Professor Balduíno Cardoso e da Escola Complementar anexa a este, constituiu-se em localizar os materiais disponíveis, catalogá-los, elaborar fichas sinópticas com o conteúdo desses, fotografar e registrar em arquivo digital (Acervo Nucathe), realizando a transcrição.

\section{COLÉGIO SANTOS ANJOS NO PLANALTO NORTE CATARINENSE (PORTO UNIÃO - SC)}

O Colégio Santos Anjos foi fundado, no ano de 1917, pelas Irmãs Missionárias Servas do Espírito Santo (MSSpS) pertencentes a uma congregação de origem alemã. A construção inicial, que abrigou a escola, funcionou em um prédio em madeira, doado pela comunidade local (Fotografia 5). A educação seguia os pressupostos católicos romanizados, propondo-se a evangelizar pessoas. As religiosas chegaram ao município de Porto União (SC), encorajadas pela insistência do pároco local. (KLEIN, 2016).

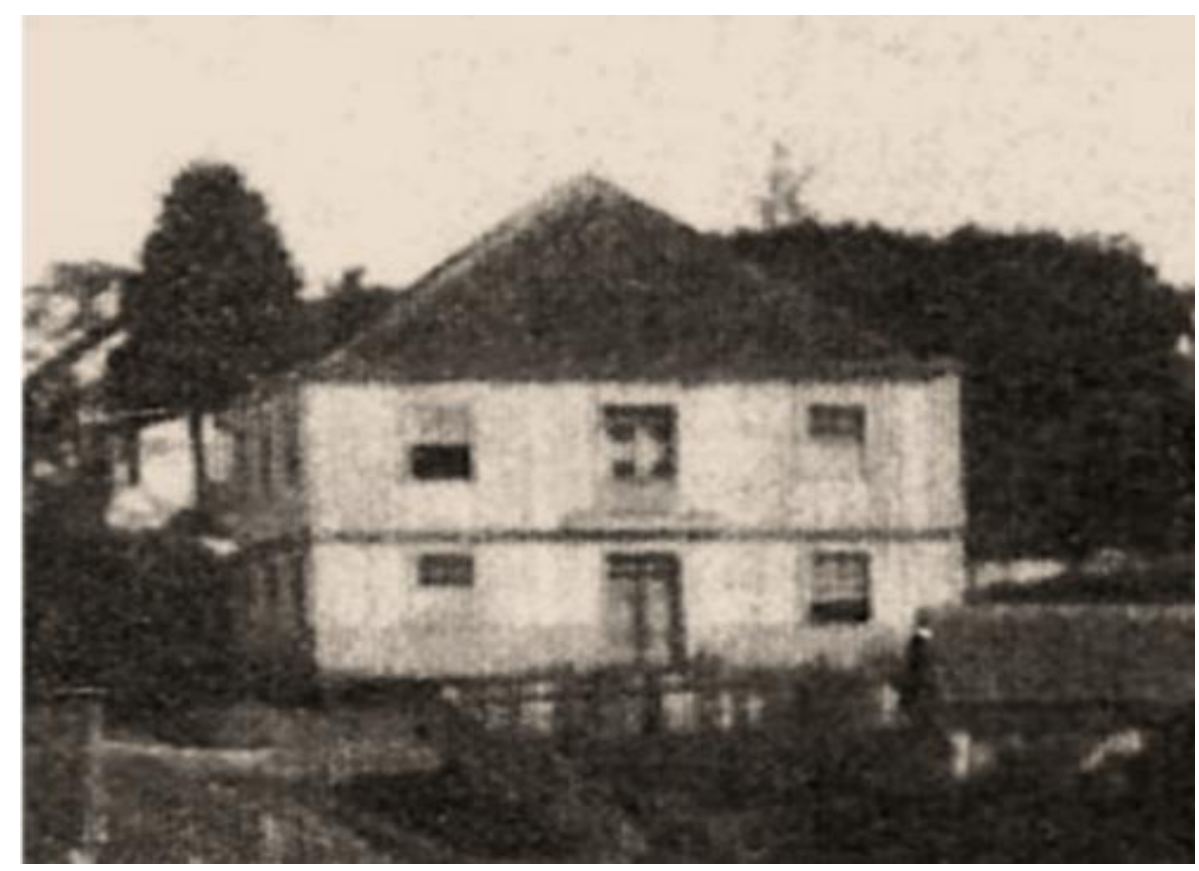

Fotografia 5 - Colégio Santos Anjos em Porto União. Fonte: Acervo do Colégio Santos Anjos, 1917.

As irmãs fundaram uma Escola Primária e o Colégio Interno Primário para as meninas ${ }^{14}$. Na década de 1930, além do Curso Primário foi criada uma Escola Complementar e o Curso Normal; em 1935, o Jardim de Infância; em 1943, o Curso Ginasial funcionou concomitante ao Curso Fundamental ${ }^{15}$. A instituição formou as meninas e as moças da Região Sul do Paraná e do Planalto Norte de Santa Catarina, mas também recebeu estudantes 


\section{Revista HIISTEYIDIR On-line}

de outros estados brasileiros. Atualmente o estabelecimento de ensino atende a Educação Básica, desde a Educação Infantil. (KLEIN, 2016).

$\mathrm{O}$ arquivo do Colégio Santos Anjos constitui-se uma especial "caixa de surpresa" por possuir um material histórico riquíssimo, composto por sessenta (60) fontes primárias inexploradas. O educandário possui material manuscrito de grande valor, álbuns de formatura das primeiras turmas de normalistas, mantém fotografias impecáveis (cerca de 1000 fotos), guarda um museu escolar da década de 1940 com objetos ainda resultantes de uma pedagogia ativa, com: coleções de pedras, quadros intuitivos, animais empalhados, instrumentos de laboratórios, mapas, pianos, entre outros. O arquivo preserva os livros de crônicas das primeiras religiosas, manuscritos em língua alemã. Possui um acervo de cinqüenta e três (53) fontes secundárias (livros didáticos e literatura) em perfeito estado. Entre os documentos, possui um parecer histórico do ano de 1944, assinado por Gustavo Capanema, autorizando o funcionamento do Curso Ginasial para as moças, entre outros. (COLÉGIO SANTOS ANJOS, 1942-1944).

As escolas religiosas de origem étnica foram fortemente "vigiadas" pelos inspetores escolares, principalmente na década de 1930, em decorrência dos ideais nacionalistas. O documento transcrito a seguir deixa transparecer essa preocupação com a nacionalização, quando o inspetor escolar visitou a instituição e emitiu o parecer no ano de 1929. O Inspetor, também Deputado da Assembleia Legislativa do Estado de Santa Catarina e Chefe Escolar do Município, Cid Gonzaga, retratou a preocupação, na época, de incutir nas crianças, via educação primária, o amor à Pátria, o civismo e principalmente a língua nacional, por meio de ensinamentos em colégios religiosos, e assim registrou:

Na qualidade de Deputado da Assembleia Legislativa do Estado e Chefe Escolar do Município, não posso deixar de congratular-me com a população desta cidade, pelo resultado que acabo de verificar no Collégio dos Santos Anjos, das Irmãs Servas do Divino Espírito Santo. Examinando as aulas, fiquei agradavelmente impressionado com o aproveitamento dos alumnos, pois desde o primeiro ao quinto ano escolar, todas as crianças sahiram-se bem, do ligeiro exame a que foram submettidas, respondendo com acerto as perguntas das diversas matérias do respectivo curso. A disciplina mantida no estabelecimento é digna de nota e o material escolar satisfaz perfeitamente as exigências da pedagogia moderna. Despertou-me também vivo interesse o gabinete de história natural physica, chimica e os trabalhos manuais dos alumnos. Na visita ao dormitório das internas encontrei ali o maior conforto e asseio, gemiflectindo-se, porém, a minh'alma ao penetrar na capella onde lindas imagens presidem aquelle santuário de virtudes christãs, ao serviço da alphabetização do Brasil. E como esquecer? Exultou de júbilo a minh'alma de patriota ao ouvir as sonoras melodias do Hymno Nacional que, de pé, com respeito, cantaram aquellasboccas e corações pequeninos. São brasileira todas estas crianças? - Sim! As que não nasceram no Brasil, amam já esta Pátria como a sua. - A Fé Christã pelas mãos piedosas das Servas do Espírito Santo, está moldando-lhes uma alma brasileira. - É uma grande missão: servir a Deus e a Pátria! Aqui deixo, pois, os meus applausos e louvores as Servas do Espírito Santo, especialmente à Irmã Superiora a quem se deve a orientação segura 


\title{
Revista HIISTEYIDIR On-line
}

do estabelecimento e com muita simphatia e respeito firmo-me, Cid Gonzaga. 1929. (GONZAGA, 1929, p. 01, anverso).

Com esse registro, verifica-se que o forte movimento nacionalista, difundido no Brasil, também esteve presente no cotidiano escolar desta instituição a partir da década de 1920. Desejava-se incutir na criança um conteúdo moral e cívico, com acentuado fervor patriótico. Não fossem esses registros armazenados nos arquivos escolares, não seria possível contar a história da educação brasileira, com suas peculiaridades regionais.

O pequeno Colégio, construído em 1917, foi sofrendo alterações arquitetônicas e tornou-se imponente. Na década de 1940, abrigou várias salas laboratórios, conforme verifica-se nos registros do inspetor federal Elpídio Caetano da Silva, por ocasião da aprovação do espaço escolar para o funcionamento do Curso Ginasial para as moças, no ano de 1943:

\begin{abstract}
O espaço interno do Colégio Santos Anjos estava dividido em amplas salas, cada uma delas com uma função específica. A descrição do espaço físico prossegue: [...] a) Salas de Trabalhos Manuais no $1 .^{\circ}$ andar, com mesas e cadeiras para as alunas, um grande armário para os trabalhos, quatro máquinas de costura, e os demais apetrechos para a boa execução dos trabalhos. b) Biblioteca, sala contigua, com armário e estantes de livros a disposição das professoras e alunas, mesas e cadeiras para as horas da consulta e frequência da biblioteca. c) Sala de Desenho, no 2. ${ }^{\circ}$ andar, sala espaçosa e clara [...]. d) Sala de Geografa e História, igualmente instalada no $2 .^{\circ}$ andar, possui todo o aparelhamento necessário ao ensino desta matéria [...]. e) Sala de Física e História Natural em forma de anfiteatro. Possui grande número de aparelhamento e instalações necessárias para o ensino de ciências físicas e naturais [...]. f) Laboratório de Química separado da sala anterior possui boa coleção de drogas para as experiências, aparelhos para reação química, mesa de laboratório com tampa de vidro, instalação de água, força elétrica e quadro negro. g) Gabinete Dentário, instalado recentemente, com todo aparelhamento necessário, é destinado ao uso das alunas internas. h) Gabinete Biométrico de acordo com as prescrições legais e das finalidades previstas. i) Pequena Farmácia com drogas, remédios e materiais necessários aos primeiros socorros. (COLÉGIO SANTOS ANJOS, 1943-1948, p. 3).
\end{abstract}

A descrição ressalta as salas especiais revelando processos de mudança, de transformação, deixando transparecer uma prática pedagógica nova, experimental e científica, que fez parte da pedagogia moderna e, mais tarde, da Escola Nova que se queria implantar. Esses fazeres adentraram os grupos escolares e, por conseguinte, as escolas confessionais que desejavam atender às elites que aspiravam por uma educação moderna para seus filhos. Esses detalhes somente tornam-se possíveis mediante uma transcrição criteriosa, viabilizada pela existência desses arquivos escolares que surpreendem com a riqueza de informações.

As fontes encontradas, nos arquivos dessa escola, proporcionaram conhecer as práticas educativas efetivadas no interior da instituição por meio das orientações dos inspetores escolares quando realizavam as visitas rotineiras. As observações minuciosas 
atribuíam, entre as muitas tarefas da professora primária, em 1938, o preenchimento do livro de chamada, recomendando que:

É preciso separar no livro de chamada os alunos das alunas. Diariamente, ao começar a aula fazer a chamada dos alunos anotando com $\mathrm{C}$ os comparecimentos e com $\mathrm{F}$ as faltas. Ao terminar o recreio fazer novamente a chamada, cortando com um traço inclinado os $\mathrm{CC}$ dos que tiverem se retirado e os FF dos que tiverem chegado depois da chamada inicial. Em seguida o nome dos comparecidos e as faltas e escreva o seu número nas respectivas colunas ao lado do dia do mês. Deixe transcrito na coluna <observações> o resumo do boletim e motivo enviado ao diretor de Departamento de Educação. (COLÉGIO SANTOS ANJOS, 1938-1949, p. 01).

Consideradas as especificidades da pesquisa, Julia (2001) refere-se a esse detalhismo de ritualização e rotinização como uma inculcação do habitus que se cristaliza nos fazeres escolares, ou seja, o indivíduo capta a intenção dos fazeres e os transforma em aptidão natural. A escola torna-se local de transmissão de fragmentos da cultura, portanto a assimilação de valores incutidos no habitus faz parte da Cultura Escolar. As fontes deixam transparecer a cultura escolar gerada no ambiente institucional.

Os documentos produzidos no cotidiano dessas escolas e que foram preservados até os dias atuais, tornam-se imprescindíveis para a compreensão e escrita da história. Revelam aspectos da organização didático pedagógica, processos avaliativos, condições materiais dos estabelecimentos, atuação docente, formação discente, cultura produzida no ambiente escolar, entre outros. Como se refere Pintassilgo e Pedro (2012, p. 16) “[...] conhecer um arquivo de uma instituição possibilita conhecer todo um mundo de especificidades e características que, de outra forma, não seria possível."

\section{CONSIDERAÇÕES FINAIS}

Em nove anos de atividades, o Nucathe consolidou-se como um espaço de descoberta e preservação de fontes para a pesquisa em História da Educação na região Sul do Paraná e planalto norte catarinense. A região do Contestado apresenta peculiaridades na organização da educação e as características desse processo são conhecidas e compreendidas a partir da história resgatada no acervo pertencente às três instituições escolares centenárias. Soma-se à pesquisa e cadastro de acervos históricos, a criação de um museu pedagógico, a escrita de trabalhos de conclusão de curso e publicações de estudos em eventos nacionais e internacionais.

Com esse trabalho, busca-se construir um conjunto de conhecimentos acerca da educação regional, relacionando-a ao contexto nacional e internacional. Os materiais catalogados oportunizam a elaboração de outras pesquisas que ampliam a compreensão do processo socioeducacional, da abrangência da legislação e da educação como parte de um projeto para conformação do cidadão brasileiro, mas também de construção da identidade 
dos habitantes do Estado de Santa Catarina e do Paraná, na região que se constituiu como palco da Guerra do Contestado.

\section{REFERÊNCIAS}

AURAS, M. O contestado: a formação da irmandade cabocla. Florianópolis, SC: Ed. da UFSC, 1983.

CAMARGO, M. Ofício ao diretor da Instrução Pública Claudino Rogoberto dos Santos em 25 de janeiro de 1913. Ofícios. v. 3, n. 1459. Curitiba, 1913. (Arquivo Público).

COLÉGIO Santos Anjos em Porto União. Acervo do Colégio Santos Anjos. Porto União, SC, 1917. 1 fotografia.

COLÉGIO SANTOS ANJOS. Chronik des Hauses. Criação do Colégio Santos Anjos em 7 de abril de 1917. Porto União, SC, 1917. p. 1.

COLÉGIO SANTOS ANJOS. Livro de chamada do curso primário. Porto União, SC, 1938-1949.

COLÉGIO SANTOS ANJOS. Livro de registro de visitas do inspetor escolar. Porto União, SC, 1943-1948.

COLÉGIO SANTOS ANJOS. Processo de criação do Ginásio Santos Anjos. Porto União, SC, 1942-1944.

ESCOLA COMPLEMENTAR ANEXA AO GRUPO ESCOLAR PROFESSOR BALDUÍNO CARDOSO. Atas de exames da Escola Complementar anexa ao Grupo Escolar Professor Balduíno Cardoso. Porto União, SC, 1928-1938.

ESCOLA COMPLEMENTAR ANEXA AO GRUPO ESCOLAR PROFESSOR BALDUÍNO CARDOSO. Livro de matrícula para a secção feminina da Escola Complementar annexa ao Grupo Escolar Professor Balduíno Cardoso. Porto União, SC, 1928-1964a.

ESCOLA COMPLEMENTAR ANEXA AO GRUPO ESCOLAR PROFESSOR BALDUÍNO CARDOSO. Livro de matrícula para a secção masculina da Escola Complementar annexa ao Grupo Escolar Professor Balduíno Cardoso. Porto União, SC, 1928-1964b.

ESCOLA COMPLEMENTAR ANEXA AO GRUPO ESCOLAR PROFESSOR BALDUÍNO CARDOSO. Livro de promoção dos alunos do Grupo Escolar Professor Balduíno Cardoso, Escola Complementar anexa. Porto União, SC, 1930. 
Artigo

doi: $10.20396 /$ rho.v18i2.8651906

ESCOLA COMPLEMENTAR ANEXA AO GRUPO ESCOLAR PROFESSOR BALDUÍNO CARDOSO. Livro ponto dos funcionários da Escola Complementar anexa ao Grupo Escolar Professor Balduíno Cardoso. Porto União, SC, 1934-1935.

ESCOLA COMPLEMENTAR ANEXA AO GRUPO ESCOLAR PROFESSOR BALDUÍNO CARDOSO. Porto União, SC, 1928.

ESCOLA COMPLEMENTAR ANEXA AO GRUPO ESCOLAR PROFESSOR BALDUÍNO CARDOSO. Registros de Diplomas da Escola Complementar anexa ao Grupo Escolar Professor Balduíno Cardoso. Porto União, SC, 1931-1941.

ESCOLA COMPLEMENTAR PRIMÁRIA ANEXA AO GRUPO ESCOLAR PROFESSOR SERAPIÃO. União da Vitória, PR, 1929.

ESCOLA NORMAL PRIMÁRIA ANEXA AO GRUPO ESCOLAR PROFESSOR BALDUÍNO CARDOSO. Atas de exames da Escola Normal Primária anexa ao Grupo Escolar Professor Balduíno Cardoso. Porto União, SC, 1938.

ESCOLA NORMAL PRIMÁRIA ANEXA AO GRUPO ESCOLAR PROFESSOR BALDUÍNO CARDOSO. Porto União, SC, 1935.

ESCOLAS REUNIDAS DE PORTO UNIÃO. Porto União, SC, 1918.

GONZAGA, C. Livro de Registro de visitas ao Colégio Santos Anjos: inspeção escolar do Colégio Santos Anjos. Porto União, SC, 1929.

GRUPO Escolar Professor Balduíno Cardoso. Acervo do Museu Municipal de Porto União, SC, [192?]. 1 fotografia.

GRUPO ESCOLAR PROFESSOR BALDUÍNO CARDOSO. Ata de reunião pedagógica. Porto União, SC, 1951-1957.

GRUPO ESCOLAR PROFESSOR BALDUÍNO CARDOSO. Porto União, SC, 1927.

GRUPO ESCOLAR PROFESSOR SERAPIÃO. Ata de exames finais da Escola da Professora Amasilia: 1915-1943. União da Vitória, PR, 1915.

GRUPO ESCOLAR PROFESSOR SERAPIÃO. Livro de registro de suspensão e de repreensão a professores e funcionários: 1937-1964. União da Vitória, PR, 1937-1964.

GRUPO ESCOLAR PROFESSOR SERAPIÃO. Registro de diplomas da Escola Complementar Primária anexa ao Grupo Escolar Professor Serapião: 1933-1943. União da Vitória, PR, 1933.

GRUPO ESCOLAR PROFESSOR SERAPIÃO. Termo de visita de inspeções escolares. União da Vitória, PR, 1929. 
HONRA ao mérito. Acervo do Grupo Escolar Balduíno Cardoso. Porto União, SC. 1952. 1 fotografia.

JULIA, D. A cultura escolar como objeto histórico. Revista Brasileira de História da Educação, n. 1, jan./jun. 2001.

KARSBURG, A. O eremita do Novo Mundo: a trajetória de um peregrino italiano na América do século XIX. 2012. Tese (Doutorado em História Social) - Universidade Federal do Rio de Janeiro, Rio de Janeiro, 2012.

KLEIN, R. B. As rotineiras "visitas" dos inspetores escolares: procedimentos e recomendações ao curso primário numa escola do planalto norte catarinense (1918 - 1945). In: CONGRESSO BRASILEIRO DE HISTÓRIA DA EDUCAÇÃO, 9., 2017, João Pessoas. Anais... João Pessoa: Universidade Federal da Paraíba, 2017. p. 2049-2058.

KLEIN, R. B. Colégio Santos Anjos, o cotidiano educativo e missionário: reflexos de uma escola alemã no planalto norte catarinense. Porto União, SC: Kaygangue, 2016.

KLEIN, R. B. Grupo Escolar Professor Serapião: 100 anos de história. União da Vitória, PR: Kaygangue, 2013.

KLEIN, R. B. O catolicismo presente no processo de escolarização: Colégio Interno Feminino no Planalto Norte Catarinense. Revista UNICAP, Pernambuco, v. 2, n. 4 jul./dez. 2015.

KLEIN, R. B. Uma reflexão sobre as disciplinas escolares e seus conteúdos: curso ginasial num colégio franciscano em Santa Catarina (década de 1940). CONGRESSO LUSO BRASILEIRO DE HISTÓRIA DA EDUCAÇÃO, 10., 2014, Curitiba. Anais... Curitiba, PR: PUC, 2014. p. 1-13.

KLEIN, R. B.; SCHENA, V. A.; STENTZLER, M. M. União da Vitória (PR) e Porto União (SC): reunindo fragmentos da história da educação na região do Vale do Iguaçu (1780 a 1930). In: SEMINÁRIO NACIONAL DE ESTUDOS E PESQUISAS HISTÓRIA, SOCIEDADE E EDUCAÇÃO NO BRASIL - HISTEDBR, 8., 2009, Campinas. Anais... Campinas, SP: UNICAMP, 2009. p. 1-18.

MACHADO, P. P. Lideranças do contestado. Campinas, SP: UNICAMP, 2004.

MILIS, H. Evolução educacional. In: FAGUNDES, J.; RIBAS, J. O. (Org.). Monografia de Porto União: Hermínio Milis. União da Vitória, PR: Kaygangue, 2002. p. 75-88.

MONTEIRO, D. T. Os heremitas do Novo Século. São Paulo, SP: Duas Cidades, 1974.

MOREIRA, J. Ata de Visita de Porto União: inspeção escolar do Grupo Escolar Professor Balduíno Cardoso. Porto União, SC, 1919. 
PARANÁ (Estado). Decreto n ${ }^{\circ} 33$ de 4 de janeiro de 1929. Cria uma Escola complementar primária e um jardim infantil anexos ao Grupo Escolar Professor Serapião de União da Vitória. Diário Oficial Estado. Curitiba: [s.n.], 21 jan. 1929.

PARANÁ (Estado). Decreto no 324 de 13 de abril de 1912. Denomina de "Professor Serapião" a Casa Escolar de União da Vitória. Curitiba: Typ. da República, 1914. (Coleção de Decretos e Regulamentos de 1912).

PINTASSILGO, J.; PEDRO, L. C. O arquivo histórico da Escola Superior de Educação de Lisboa: análise da documentação existente. In: CONGRESSO LUSO -BRASILEIRO DE HISTÓRIA DA EDUCAÇÃO, 9., 2012, Lisboa. Conferências eletrônica... Lisboa: Portugal, 2012. p. 1-16. Disponível em: <http://repositorio.ul.pt/handle/10451/10737>. Acesso em: 10 maio 2018.

PRATES, F. R. O.; TEIVE, G. M. G. “Associações auxiliares”: vestígios de apropriações escolanovistas em Grupos Escolares de Florianópolis e Brusque - SC (1947 e 1951). CONGRESSO BRASILEIRO DE HISTÓRIA DA EDUCAÇÃO, 7., 2013, Cuiabá. Anais... Cuiabá, MS: UFMT, 2013. p. 1-15.

PRÉDIO do Grupo Escolar Professor Serapião, construído em 1913. Acervo do NUCATHE. União da Vitória, PR: [s.n.]. 1 fotografia.

PRIMEIRO e segundo registro de visitas de autoridades. Acervo do Grupo Escolar Balduíno Cardoso. Porto União, SC, 1919. 1 fotografia.

SANTA CATARINA (Estado). Decreto nº 244 de 8 de dezembro de 1938. Dá nova regulamentação aos Grupos Escolares e aos Cursos Complementares. Coleção de Decretos-Leis de 1938. Florianópolis: Imprensa oficial do Estado, 1939.

SANTA CATARINA (Estado). Decreto $\mathrm{n}^{\circ} 713$ em 05 de janeiro de 1935. Novas normas para reger institutos destinados a formação do professorado e aplicação de novos métodos de ensino. Coleção de Decretos, Resoluções e Portarias de 1935. Florianópolis: Livraria Central de Alberto Entres, 1936.

SANTA CATARINA (Estado). Decreto no 2017 de 19 de janeiro de 1927. Cria o Grupo Escolar Professor Balduíno Cardoso. Colleção de Leis, Decretos e Resoluções de 1927. Florianópolis, Typ. Livraria Moderna, 1928.

SANTA CATARINA (Estado). Decreto n ${ }^{\circ} 2135$ de 12 de março de 1928. Cria uma escola complementar anexa ao Grupo Escolar Professor Balduíno Cardoso. Collecção de Leis e Decretos e resoluções de 1928. Florianópolis: Off. Graphicas da Escola de A. Artífice, 1929.

SANTA CATARINA (Estado). Lei no 1147 de 25 de agosto de 1917. Cria o Município de Porto União (SC). Collecção de leis, decretos, resoluções e portarias de 1917. Florianópolis: Officinas a ellect. da empresa D’O Dia, 1917. 
SANTA CATARINA (Estado). Resolução no 1196 de 20 de junho de 1918. Início das atividades das escolas reunidas em Porto União. Collecção de Leis e Decretos e

Resoluções de 1918. Florianópolis, SC: Officinas à ellect. da Imprensa Official, 1919.

SANTOS, E. M. dos. Relatório apresentado a Affonso Alves de Camargo, presidente do Estado do Paraná, por Enéas Marques dos Santos, secretário d'Estado do Interior, Justiça e Instrução Pública, em 31 de dezembro de 1918. Curityba: Typografia d'República, 1918.

SCHENA, V. A. Representações e apropriações da pedagogia moderna no Grupo Escolar Professor Balduíno Cardoso de Porto União-SC (1918-1957). 2015. Tese (Doutorado em Educação) - Universidade Estadual de Ponta Grossa, Ponta Grossa, PR, 2015.

SILVA, C. da. Apontamentos históricos de União da Vitória (1768-1933). Reimpressão. Curitiba: Imprensa Oficial, 2006.

STENTZLER, M. M. Entre questões lindeiras e a superação de fronteiras: a Escola Complementar em Porto União (SC) e União da Vitória (PR), 1928-1938. 2015. 181 f. Tese (Doutorado em Educação) - Universidade Federal do Paraná, Curitiba, PR, 2015.

STENTZLER, M. M.; FERREIRA, A. I. L. Termos de inspeção: o papel do inspetor escolar na avaliação didático-pedagógica e material escolar (1934). Revista Ensino \& Pesquisa, v. 14, suplemento especial, p. 36-51, 2016. Disponível em: <http://periodicos. unespar.edu.br/index.php/ensinoepesquisa/article/view/1184/621>. Acesso em: $18 \mathrm{fev}$. 2018.

STENTZLER, M. M.; KOBELINSKI, M. O Termo de inspeção de Germano Wagenfuhr (1934). Revista Ensino \& Pesquisa, v. 15, n. 4, p. 316-333, 2017. Disponível em: <http://periodicos.unespar.edu.br/index.php/ensinoepesquisa/article/view/1850/pdf_39>. Acesso em: 18 fev. 2018.

WAGENFUHR, G. Livro de Termos de Visitas das Escolas Reunidas: Registro de inspeção ao Grupo Escolar Professor Balduíno Cardoso. Porto União: Santa Catarina, 1939.

\section{Notas}

\footnotetext{
${ }^{1}$ Doutora em Educação pela Universidade Tuiuti do Paraná (UTP). Mestre em Educação pela Universidade do Contestado (UnC). Graduada em Pedagogia. Professora adjunta do Colegiado de Pedagogia da Universidade Estadual do Paraná (UNESPAR), campus de União da Vitória. Membro do Núcleo de Catalogação, Estudos e Pesquisas em História da Educação (NUCATHE). Membro da Academia de Letras do Vale do Iguaçu (Alvi).

${ }^{2}$ Doutora em Educação pela Universidade Federal do Paraná (UFPR); Mestre em Educação pela Universidade Estadual de Ponta Grossa (UEPG); Graduada em Pedagogia pela UFPR. Professora Adjunta no Curso de Pedagogia da Unespar, campus União da Vitória (PR). Coordena o Núcleo de Catalogação, Pesquisas e Estudos em História da Educação (Nucathe). Membro da Academia de Letras do Vale do Iguaçu (Alvi). Avaliadora do Mec/Inep para cursos de graduação.
} 


\section{Revista HIISTEYDIBR On-line}

${ }^{3}$ O início do trabalho contou com o apoio e orientação das Professoras Ms. Leni Trentim Gaspari e Dra. Theresa Jussara Luporini, instigando professores e acadêmicos do Curso de Pedagogia da Universidade Estadual do Paraná (Unespar), campus de União da Vitória, a conhecer, catalogar, fotografar, acondicionar e publicar pesquisas com base em documentos históricos.

${ }^{4} \mathrm{O}$ Rio Iguaçu nasce próximo à capital do Estado do Paraná (Curitiba). A região em estudo denomina-se Vale do Iguaçu, por possuir essa característica e contempla as cidades de União da Vitória (sul do Paraná) e Porto União (norte de Santa Catarina). As cidades formam um único conjunto urbano. São separadas geograficamente pelos trilhos do trem da antiga estrada de ferro que ligava São Paulo ao Rio Grande do Sul.

${ }^{5}$ Pelo Decreto ${ }^{\circ}$ 54, de 27 de março de 1890, "Art. 1. Fica ellevada a cathegoria de Villa a Freguezia da União da Victoria" Pelo Decreto $n^{\circ}$ 55, da mesma data, "Fica creada a Intendência Municipal na Villa União da Victoria.” (SILVA, 2006, p. 59). Localizada no Vale do Iguaçu, região do Médio Iguaçu, desenvolveu-se até 1905, tendo a navegação como principal meio para o transporte até a cidade de Porto Amazonas (PR).

${ }^{6}$ A Guerra do Contestado ocorreu entre os Estados do Paraná e de Santa Catarina (1912-1916), envolvendo sertanejos, madeireiras, entre outros. O artigo não aprofunda a discussão sobre a Guerra do Contestado. Sugerese consultar os seguintes estudos: Auras (1983); Karsburg (2012); Monteiro (1974); Machado (2004), entre outros.

${ }^{7}$ Definitivamente estabelecido pelo Decreto Federal no . 3304, em 3 de agosto de 1917. (SILVA, 2006, p. 160). ${ }^{8}$ Neste artigo utilizaremos a denominação Grupo Escolar Professor Serapião para o estabelecimento de ensino que existiu na cidade de União da Vitória. Mas, conforme aponta o Relatório da Instrução Pública paranaense (SANTOS, 1918, p. 8), o processo de remodelação do estabelecimento ocorreu em 1919 objetivando "[...] estimular, organizar e orientar metodologicamente os professores.” (STENTZLER, 2015, p. 61-62).

${ }^{9} \mathrm{O}$ prédio histórico localiza-se na área central da cidade de União da Vitória (PR), junto à Praça Coronel Amazonas.

${ }^{10}$ Em 1918, o professor Júlio Machado da Luz, foi designado para auxiliar o serviço de instalação das Escolas Reunidas de Porto União. Em 13 de agosto de 1918, foram nomeadas as duas primeiras normalistas de Porto União. Em 26 de agosto de 1918, o professor Antenor Cidade foi nomeado como Diretor das Escolas Reunidas de Porto União. Em 28 de setembro de 1918, aconteceu a inauguração das Escolas Reunidas de Porto União, funcionando nas antigas instalações do Grupo Escolar Professor Serapião. (STENTZLER, 2015).

11 A Escola Complementar de Porto União (SC) nasceu da necessidade de formação de professores para lecionar em escolas primárias, particularmente nas áreas rurais da região do ex-Contestado. A Escola Complementar funcionava no mesmo prédio do Grupo Escolar Professor Balduíno Cardoso, Porto União (SC). As professoras eram as normalistas que, em turno contrário lecionavam no Grupo Escolar. Dessa forma, a criação da escola não onerava os cofres públicos e a municipalidade contribuía com um valor pré-estabelecido para a manutenção. No ano de 1935 várias Escolas Complementares catarinenses transformaram-se em Escolas Normais Primárias, ofertando a disciplina de Noções de Pedagogia e Psicologia. No ano de 1938 foram extintas e em seu lugar criado o Curso Complementar, perdendo o caráter de formação de professores existente nas Escolas Normais Primárias. (STENTZLER, 2015).

${ }^{12}$ A transcrição das referidas fontes faz parte de um trabalho de catalogação, em andamento, a ser publicado, pela pesquisadora Professora Roseli Bilobran Klein (Unespar, campus de União da Vitória).

13 Os fragmentos de fontes catalogadas e transcritas, apresentadas nesse artigo, foram registrados aleatoriamente. Não obedecem a uma ordem cronológica, servem como uma amostra do trabalho realizado pelo Nucathe, vinculado ao Curso de Pedagogia da Universidade Estadual do Paraná, campus de União da Vitória. O propósito de registrar esses fragmentos não suscita a intenção de realizar uma análise, apenas mostrar a potencialidade dos arquivos escolares como fonte de pesquisa para a história da educação brasileira.

${ }^{14}$ A escola recebeu os meninos como alunos externos até aproximadamente o final da década de 1950, porém em menor número. Entretanto, a frequência dos meninos limitava-se ao Curso Primário. (KLEIN, 2016).

15 O Curso Complementar foi criado em 1929. A princípio teve a duração de três anos, poderia ser cursado após o Curso Primário, qualificando as meninas a lecionarem em escolas primárias, na maioria das vezes em escolas rurais e multisseriadas. O Curso Normal foi criado nesse mesmo ano, poderia ser cursado após o Curso Complementar, possibilitando as moças a lecionarem no Curso Primário, incluindo os Grupos Escolares. O Curso Fundamental foi uma modalidade de ensino oferecida entre os anos de 1939 a 1949, devido a fusão do Curso Complementar com o Curso Normal, apresentando uma duração de cinco anos. A criação do Curso Fundamental não eliminou o Curso Normal, tendo em vista que esse assumiu uma nova modalidade, denominando-se Curso Normal Secundário, a ser cursado após o Curso Fundamental ou após o Curso Ginasial, 


\section{Revista HIIS'TEIDBR On-lime}

conforme a escolha das alunas. O Curso Ginasial para as moças foi criado no ano de 1943, com duração de quatro anos. (KLEIN, 2016).

Submetido em: 09/03/2018

Aprovado em: 01/05/2018

Publicado em: 22/06/2018 